\title{
The CONCEPT OF HaRMony by CONTRaSt in ARCHitecture on The Development of Purwosari Station Area
}

\author{
KONSEP ARSITEKTUR HARMONY BY CONTRAST \\ Pada Pengembangan Kawasan Stasiun Purwosari
}

\author{
Alif Datu Nurjati Prasetyo ${ }^{1^{*}}$, Titis Srimuda Pitana ${ }^{2}$, Gunawan $^{3}$ \\ Program Studi Arsitektur, Universitas Sebelas Maret ${ }^{1}$ \\ Email : alifdatu.arch@gmail.com* \\ Program Studi Arsitektur, Universitas Sebelas Maret ${ }^{2}$ \\ Program Studi Arsitektur, Universitas Sebelas Maret ${ }^{3}$
}

\begin{abstract}
Conservation is an effort to preserve historical buildings and processes to limit the changes considering on past, present, and future aspects. Conservation at the Purwosari station area is applied as the basis for the development of the cultural heritage station building. Harmony by Contrast is one of the conservation efforts used in handling the preservation of the area by maintaining the harmony between new buildings with old buildings, maintaining the harmony of urban spaces and other urban elements without having to undermine the existence of old buildings. Purwosari Station in Surakarta comes as a large station building as well as a cultural heritage building, accommodating the transit of arrival and departure of passengers. In its development, population growth more and more so that station Purwosari require development of design enough to accommodate passenger transit activity. Appropriate design's planning is needed to realize a safe and convenient transit area. Because of that, it will be applied the evaluation-design-strategy to giving the attention about the aspects need to be addressed as well as to be developed with the approach of harmony by contrast's architecture.
\end{abstract}

Keywords: Harmony by Contrast, station building, transpotation.

\section{PENDAHULUAN}

Perkembangan zaman yang begitu pesat dan kemajuan teknologi yang semakin canggih menjadikan mobilisasi sebagai salah satu kebutuhan utama manusia. Moda transportasi sebagai sarana pendukung untuk mobilisasi menjadi salah satu unsur yang memegang peranan penting dalam keberlangsungan hidup manusia. Oleh karena itu, moda transportasi dituntut untuk serba cepat dan tepat serta memberikan ruang yang nyaman dan aman sebagai sarana mobilisasi manusia.

Moda transportasi yang dipilih oleh sebagian besar penumpang adalah kereta api karena nyaman, tanpa hambatan, tarif murah, dan lokasi stasiun yang mudah dijangkau. Hal tersebut dapat dilihat dari data PT. KAI bahwa pertumbuhan volume penumpang kereta api di Indonesia cukup signifikan. Jumlah volume penumpang kereta api tahun 2013 mencapai 221 juta penumpang, meningkat $9,29 \%$ dari tahun 
sebelumnya. Sementara itu, penumpang kereta api menuju Kota Surakarta pada tahun 2015 meningkat $12 \%$ dari tahun sebelumnya, sedangkan penumpang yang berangkat dari Kota Surakarta dengan menggunakan kereta api meningkat $15 \%$ dari tahun sebelumnya (www.solopos.com).

Stasiun Purwosari adalah stasiun terbesar kedua di Kota Surakarta yang kondisinya cukup padat, semenjak Stasiun Solo Jebres dipreservasi oleh Pemerintah Kota Surakarta sebagai bangunan cagar budaya, aktivitas naik-turun penumpang jalur selatan di pusatkan di stasiun Purwosari. Stasiun Purwosari terletak di jalan Wilheminastraat yang sekarang menjadi jalan Slamet Riyadi yang tepat berada di jantung kota Solo. Pemilihan stasiun Purwosari pada jalan Wilheminastraat difokuskan pemerintah pada zamannya demi memberikan fasilitas perkotaan khususnya diperuntukan oleh etnis Eropa sebagai strata paling atas diwilayah kerajaan dan memberikan ciri modernisasi budaya perkotaan di kota Solo (Martin, Auditya. (2009). Transportasi Kereta Api Dalam Pembangunan Kota Solo Tahun 1900-1940)

Kedepannya, Stasiun Purwosari akan menjadi stasiun yang padat, tidak hanya digunakan sebagai stasiun utama pemberhentian dan pemberangkatan kereta api ekonomi jalur selatan, tapi juga kereta komuter KRL SoloJogja yang sedang dalam tahap perencanaan, dan tidak menutup kemungkinan untuk kereta bandara. Faktanya, keadaan ruang eksisting Stasiun Purwosari belum mampu mewadahi perkembangan kegiatan kedatangan dan keberangkatan penumpang yang semakin padat untuk saat ini dan kedepannya. Oleh karena itu, perlu adanya pengembangan di kawasan Stasiun Purwosari.

Menurut Rencana Pembangunan Jangka Panjang Kawasan Stasiun Purwosari tahun 2005-2025 Pemerintah Kota Surakarta, bagian barat stasiun area perlintasan rel kereta dengan jalan raya akan dibangun fly-over untuk mengantisipasi semakin padat dan melonjaknya arus kendaraan dan penumpang yang lewat ataupun menuju Stasiun Purwosari. Selain itu, pihak Unit Preservation and Architecture PT. KAI juga akan melakukan pengembangan Stasiun Purwosari kedepannya di sisi utara.

Pengembangan Stasiun Purwosari yang direncanakan adalah dengan menghadirkan bangunan baru yang sesuai dengan perkembangan zaman dengan tetap mengapresiasi lingkungan sekelilingnya serta sesuai Standar Pelayanan Minimum Angkutan Orang Dengan Kereta Api yang dikeluarkan Kementrian Perhubungan Republik Indonesia. (2015) dan Pedoman Teknis Pembangunan Bangunan Gedung Negara Kementrian Pekerjaan Umum Republik Indonesia (2007). Konsep desain harmony by contrast menjadi solusi pengembangan Stasiun Purwosari agar bangunan baru yang direncanakan tetap harmonis dengan kondisi eksisting yang merupakan bangunan cagar budaya.

Harmony by contrast merupakan salah satu pendekatan yang dipakai dalam penanganan pelestarian kawasan dengan menjaga keselarasan antara bangunan baru dengan bangunan lama, menjaga keselarasan ruangruang kota dan elemen kota lainnya tanpa harus melemahkan eksistensi bangunan lama. Pendekatan harmony by contrast pada suatu kawasan adalah dengan bebas melakukan inovasi pembangunan baru, tetapi masih menjaga keharmonisan elemen rancang kotanya dengan kawasan lainnya. Pada kawasan ini dapat dilakukan perombakan total terhadap bangunan lama yang bukan bangunan cagar budaya. Apabila terdapat bangunan cagar budaya pada kawasan ini, maka bangunan tersebut tetap dipertahankan. Sedangkan bangunan baru di sekitar bangunan cagar budaya tersebut dapat dibangun dengan bentuk yang berbeda (kontras). Diharapkan keberadaan bangunan cagar budaya tersebut dapat ditonjolkan karena perbedaan tersebut.

Pada prinsipnya, harmony by contrast merupakan perpaduan dari harmony (selaras) dan contrast (berlawanan). Harmoni yang dimaksutkan dalam harmony by contrast adalah bagaimana menciptakan keselarasan dalam suatu lingkungan dengan kekentalan nilai 
sejarah yang tinggi. Sehingga dapat dikatakan bahwa dalam strategi desain harmoni, daripada menyaingi karakter bangunan lama, kehadiran bangunan baru lebih kepada menunjang atau menjadi latar bagi bangunan yang sudah ada walaupun terlihat dominan. Prinsip dasar pendekatan selaras (Faatihah, 2014) yaitu optional, selective linkage, moderate conformance, rigorous conformance, dan replication.

Sedangkan kontras dalam menciptakan lingkungan urban yang menarik merupakan suatu metode kontekstualisme yang tepat. Kontras merupakan suatu strategi desain yang berpengaruh, karena jika diaplikasikan dengan kondisi yang tepat maka akan menjadi citra suatu kawasan, namun jika tidak sesuai dengan kondisinya akan menimbulkan kekacauan dan merusak citra kawasan. Hal tersebut sesuai dengan pendapat Brent $C$. Brolin dalam Architecture in Context yang menyebutkan bahwa kontras pada bangunan lama dan bangunan baru merupakan sebuah keselarasan, namun perlu diperhatikan porsinya. Bila akibat yang ditimbulkan oleh kontras terlalu banyak, maka efektifitas yang dikehendaki akan menurun sehingga akan mengakibatkan kekacauan. Prinsip dasar pendekatan kontras yaitu penggunaan intensitas perbedaan yang ekstrim pada warna, gaya, struktur bangunan, bentuk, dan material; serta nilai estetis yang dapat ditimbulkan melalui pelibatan interaksi beberapa faktor yang mengakibatkan banyaknya variasi dan situasi yang mendorong penggunaan pendekatan kontras.

Berdasarkan prinsip harmony by contrast di atas, maka dapat disimpulkan bahwa kriteria bangunan dengan konsep desain harmony by contrast adalah; (a) Langgam/gaya arsitektur, skala, material, warna, dan konstruksi dapat sangat berbeda dengan bangunan eksisting yang dilestarikan; (b) Ruang luar/RTH, bangunan cagar budaya tetap menonjol di antara bangunan baru yang berbeda sama sekali; dan (c) Signage dan street furniture dapat ditentukan berdasarkan tema pada kawasan tersebut.

\section{METODE PENELITIAN}

Metode penelitian yang digunakan adalah penelitian evaluasi (applied research) melalui pendekatan deskriptif kualitatif. Evaluasi purna huni pada Stasiun Purwosari berfokus pada tiga aspek, yaitu aspek teknis, fungsional, dan perilaku. Aspek teknis merujuk pada pencahayaan yang minim pada siang hari khususnya saat ada rangkaian kereta yang berhenti di stasiun.

Aspek fungsional merujuk pada tidak adanya fasilitas toilet pada zona umum seperti ruang tunggu pembelian tiket, area parkir dan hall stasiun; ketidakjelasan penanda zona pelayanan; tidak terdapat restoran atau kedai pada area zona tiga (hanya terdapat sebuah minimarket); tidak terdapat restoran atau minimarket pada zona umum; dan ukuran hall $42 \mathrm{~m}^{2}$; minimnya fasilitas sirkulasi bagi para difabel seperti ramp; dan beberapa signage atau penanda tidak berfungsi sesuai dengan keterangan signage.

Sedangkan aspek perilaku merujuk pada tidak adanya pembatas yang jelas antara area pemeriksaan tiket dan mencetak tiket sehingga sering terjadi simpul kepadatan yang mengakibatkan penumpukan penumpang; area peron digunakan sebagai area duduk-duduk, hal tersebut dikarenakan kapasitas ruang tunggu yang tidak memadai saat peak season; tidak adanya fasilitas pedestrian di depan bangunan stasiun; banyaknya calon penumpang backpacker yang tidur di emperan stasiun dikarenakan tidak adanya ruang khusus yang disediaan bagi para backpacker; dan area komersial kurang beragam menyebabkan sebagian kebutuhan pengguna tidak terpenuhi.

Dari hasil penelitian evaluasi purna huni, didapatkan data sebagai pertimbangan untuk proses perencanaan dan perancangan pengembangan kawasan stasiun Purwosari dengan pendekatan arsitektur harmony by contrast. Arsitektur harmony by contrast ini akan menjadi dasar dalam pemilihan langgam / gaya arsitektur, material, warna, konstruksi, juga skala dalam proses pengembangan ruang dalam desain. 


\section{HASIL DAN PEMBAHASAN}

Penerapan desain harmony by contrast pada perancangan pengembangan Stasiun Purwosari digunakan pada tampilan bangunan sehingga dapat mewujudkan suasana ruang yang berbeda (kontras) namun tetap merangkul bangunan eksisting cagar budaya (harmoni) yang ada. Berdasarkan kajian pustaka dan eksplorasi yang dilakukan sebelumnya, maka penerapan desain harmony by contrast pada tampilan bangunan dilakukan dengan memperhatikan 5 poin, yaitu langgam / gaya arsitektur, skala, material, warna, dan konstruksi.

\section{a. Langgam / gaya arsitektur}

Arsitektur Stasiun Purwosari yang dibangun pada tahun 1870 ini didesain untuk stasiun kelas besar pada zaman Netherlands Indische Spoorwegs. Berdasarkan bentuk atap, ornamen, dan material bangunan, Stasiun Purwosari memiliki langgam ekspresionis (lihat gambar 1).

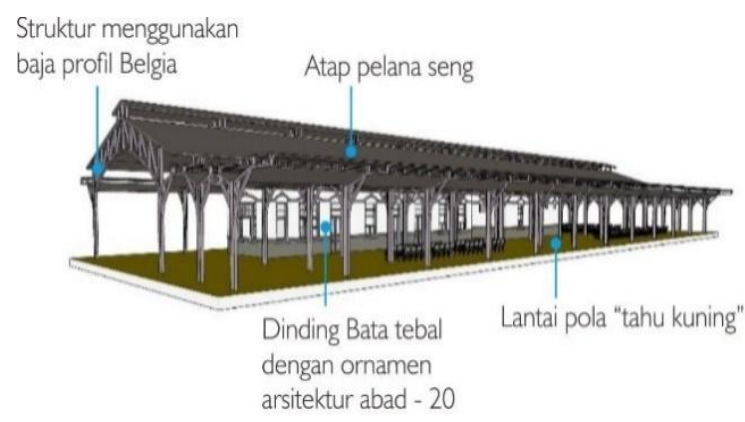

Gambar 1. Bangunan eksisting stasiun Purwosari

Hal ini juga terlihat dari beberapa campuran langgam yang muncul pada desain bangunan, antara lain: langgam tropis, berlage, dan art noveau.

Langgam merupakan saksi sejarah yang berkembang pada suatu zaman. Untuk menandai keberadaan pengembangan Stasiun Purwosari yang baru, maka digunakan langgam post-modern yang sedang berkembang saat ini (lihat gambar 2). Selain sebagai penanda zaman, langgam merupakan salah satu aspek kekontrasan yang hadir dalam desain pengembangan Stasiun Purwosari.

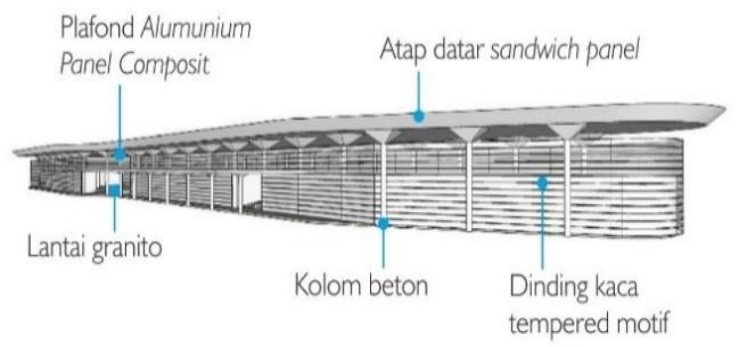

Gambar 2. Bangunan pengembangan stasiun Purwosari

b. Skala

Proses perancangan pengembangan Stasiun Purwosari ini mempertimbangkan kebutuhan fungsi ruang. Bangunan eksisting Stasiun Purwosari berfungsi sebagai stasiun commuter line (CL) sedangkan bangunan baru berfungsi sebagai stasiun kereta lintas jarak jauh (KLJJ). Bangunan baru Stasiun Purwosari tidak hanya mewadahi fungsi untuk penumpang, tetapi juga untuk pengelola stasiun, sekaligus untuk urusan perawatan dan pengelolaan stasiun. Perbedaan fungsi ruang $\mathrm{CL}$ dan KLJJ berpengaruh pada skala bangunan yang direncanakan.

Bangunan baru Stasiun Purwosari lebih panjang 2x dari bangunan eksisting (lihat gambar 3), selain menyesuaikan bentuk pola tapak yang memanjang, juga untuk memaksimalkan fungsi ruang pada kawasan stasiun. Meskipun memiliki massa bangunan baru yang cukup besar (lihat gambar 4), namun ukuran ruang berdasarkan Pedoman Standarisasi Stasiun Kereta Api Indonesia PT Kereta Api Indonesia (Persero) (2012), misalnya pembagian zona pada stasiun, ketinggian dan panjang peron untuk stasiun kereta kelas 1 . 


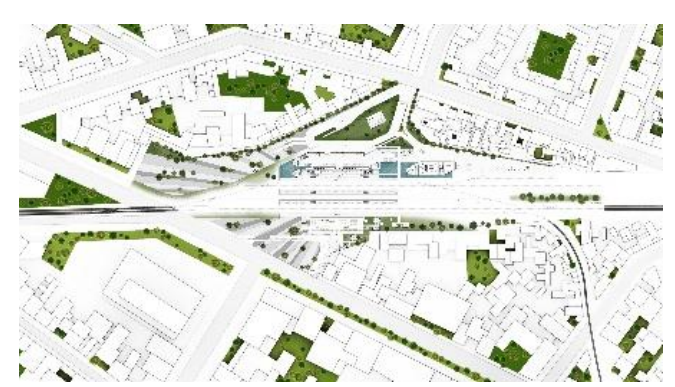

Gambar 4. Siteplan kawasan pengembangan stasiun Purwosari

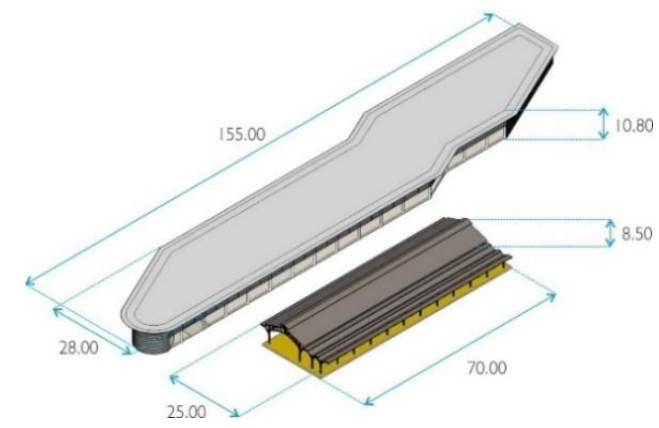

Gambar 4. Perbandingan ukuran bangunan stasiun Purwosari eksisting (kanan) dengan bangunan baru (kiri)

Bangunan stasiun baru dibuat lebih tinggi daripada bangunan stasiun lama karena secara mikro untuk menciptakan perbedaan suasana ruang antar bangunan, sedangkan secara makro untuk menciptakan keharmonisan ketinggian atap. Pada sisi selatan stasiun juga terdapat pengembangan hall CL yang memiliki atap paling rendah di kawasan stasiun Purwosari (lihat gambar 5). Beranjak naik dari posisi rendah yang berada di bangunan lama di sisi selatan ke posisi tinggi yang berada di bangunan baru di sisi utara (lihat gambar 6).

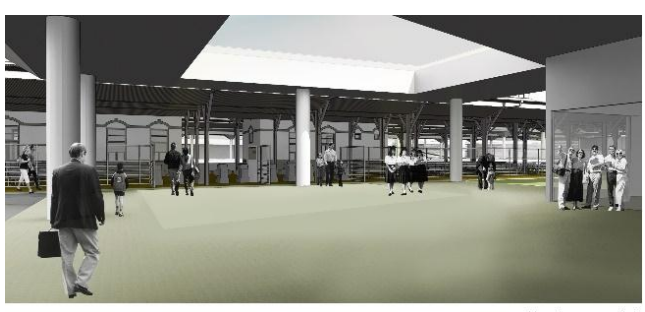

Gambar 5. Hall sisi selatan yang atapnya dibuat ketinggian paling rendah sumber

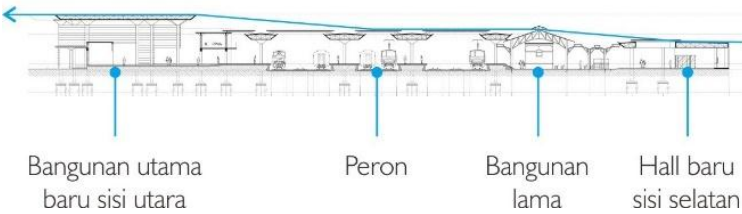

Gambar 6. Potongan pengembangan kawasan Stasiun Purwosari

c. Material

Stasiun Purwosari, merupakan bangunan stasiun buatan Belanda pada tahun 1870 . Material pada kanopi besar berbentuk hangar diatas peron dan jalur rel menggunakan konstruksi baja buatan Belgia beratap seng, material dinding yang digunakan adalah pasangan batu bata yang memiliki ketebalan $20 \mathrm{~cm}$ lebih tebal daripada batu bata zaman sekarang, dengan ornamen arsitektur abad 20, sedangkan pintu dan jendela menggunakan kusen dari material kayu jati (lihat gambar 7).

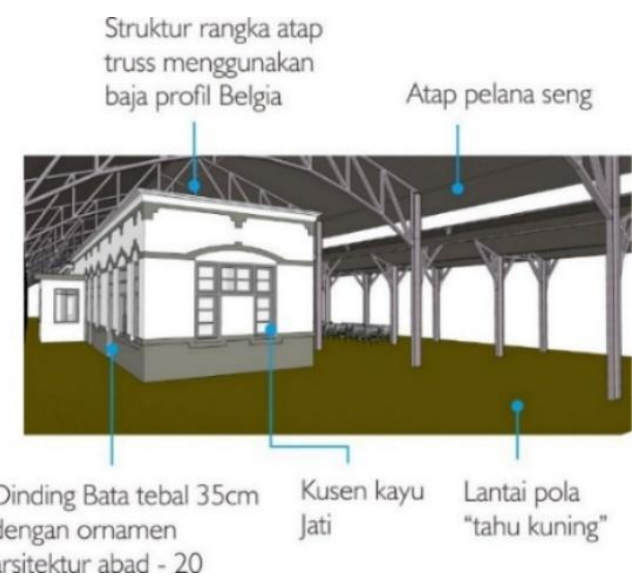

Gambar 7. Interior eksisting bangunan stasiun Purwosari

Pengembangan bangunan baru Stasiun Purwosari menggunakan material modern yang tetap mempertimbangkan keharmonian dengan bangunan eksisting. Material yang digunakan adalah beton dengan bentuk dasar lingkaran pada kolom bangunan, granito pada penutup lantai, partisi dari rangka besi hollow yang dilapisi gypsum board pada dinding antar ruang, kaca tempered dengan 
motif batik parang sebagai aspek lokalitas pada penutup kulit bangunan, naja yang dirangkai menjadi struktur spaceframe pada struktur atap, sandwich panel pada atap datar, dan aluminium composit panel yang disusun diagonal pada plafon (lihat gambar $8)$.

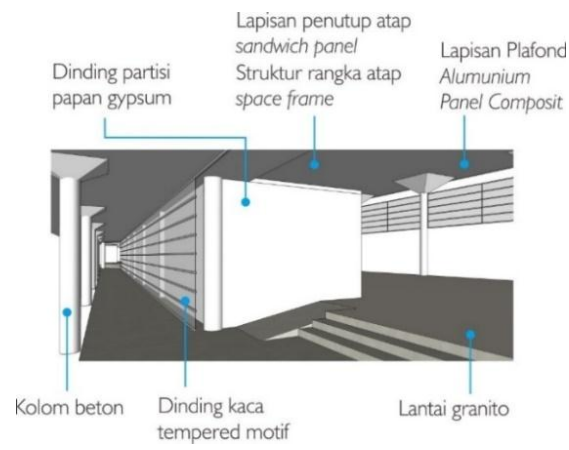

Gambar 8. Interior bangunan stasiun Purwosari baru

Pada peron juga menggunakan material modern yang tetap mempertimbangkan keharmonian dengan bangunan eksisting sama seperti bangunan utama pengembangan stasiun Purwosari. Pengadaan signage dan garis pengaman sebagai aspek pendukung dan keamanan penumpang, serta penggunaan kaca tempered laminasi yang ditopang struktur truss sebagai "kanopi" penutup peron dan pelindung agar penumpang terhindar dari tampias air hujan (lihat gambar 9).

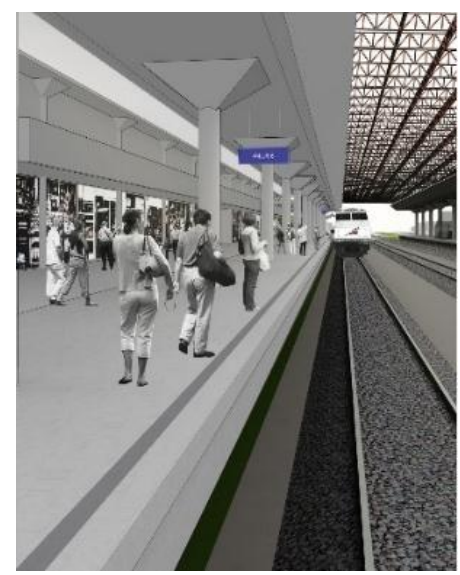

Gambar 9. Interior peron stasiun Purwosari d. Warna

Hingga saat ini, warna asli stasiun Purwosari belum bisa teridentifikasi, namun jika dibandingkan dengan stasiun-stasiun Belanda zaman dulu, mayoritas warna yang digunakan adalah warna terang, kombinasi warna putih.

Pemilihan skema warna dasar pada desain pengembangan bangunan baru menggunakan dominasi warna bersih dan netral, yaitu putih. Bangunan Stasiun Purwosari merupakan bangunan umum, sehingga penggunaan warna variasi putih memberikan kesan akrab dan tenang. Warna putih yang dipadukan dengan warna monokrom dapat memberikan kesan harmoni, sinergis, sederhana, bersih, dan minimalis (lihat gambar 10).

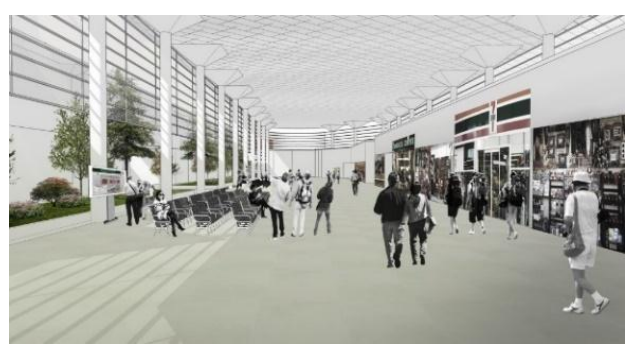

Gambar 10. Interior bangunan stasiun Purwosari baru

Sama seperti warna bangunan eksisting saat ini, kombinasi warna abu-putih menjadi sumber aspek harmoni dalam kawasan stasiun Purwosari (lihat gambar 11, 12, dan 13). Berkaca pada sejarah masa lalu, yang kini hadir menjadi cerminan di masa sekarang dan yang akan datang, bangunan stasiun Purwosari baru ini menjadi cerminan dari sejarah masa lalu yang hadir kembali pada saat ini dengan rupa yang berbeda. 


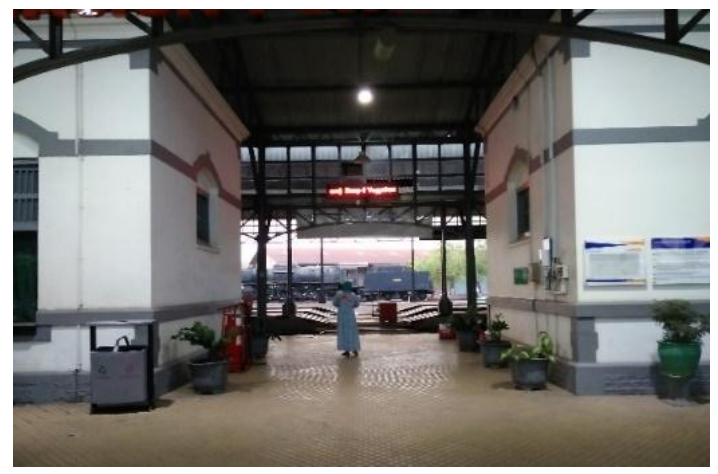

Gambar 11. Interior eksisting bangunan stasiun Purwosari

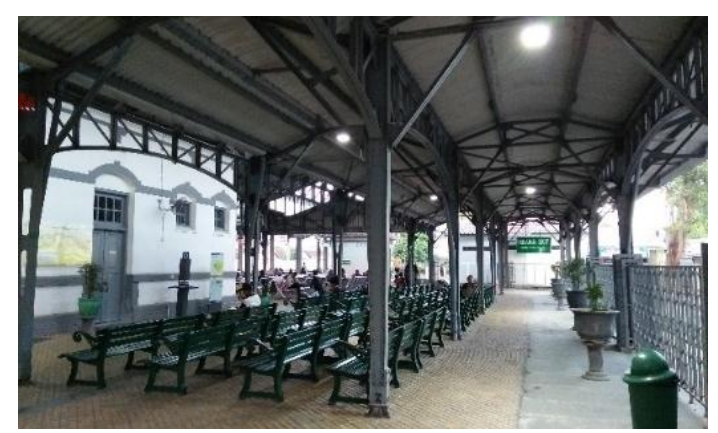

Gambar 12. Interior eksisting bangunan stasiun Purwosari

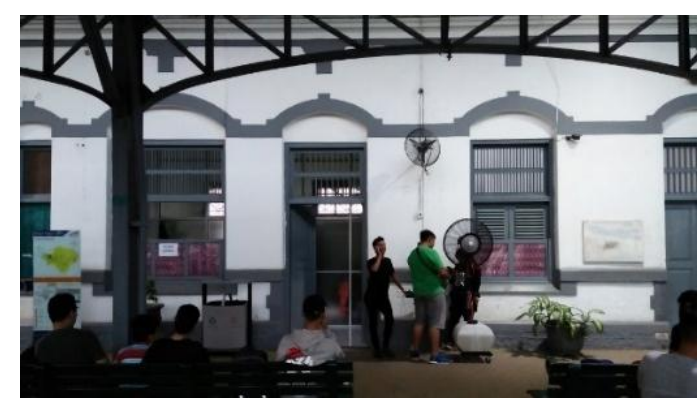

Gambar 13. Interior eksisting bangunan stasiun Purwosari

e. Konstruksi

Untuk membangun bangunan tidak akan terbangun bila tidak ada konstruksi. Konstruksi juga merupakan teknologi struktur penanda pada zamannya. Pada bangunan eksisting stasiun Purwosari menggunakan struktur rangka baja dengan dominasi jenis struktur truss (lihat gambar 14). Sedangkan pada bangunan pengembangan stasiun Purwosari menggunakan sistem konstruksi yang terbarukan saat ini.
Struktur rangka atap truss menggunakan baja profil Belgia

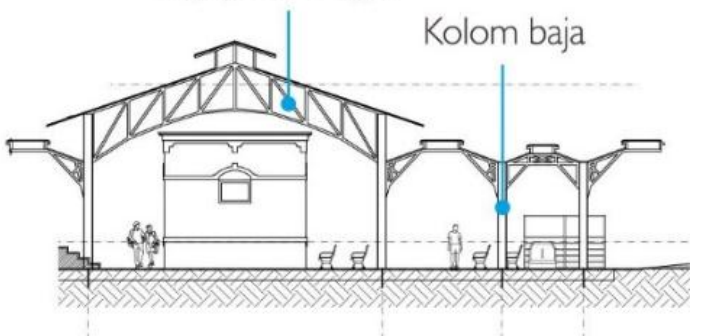

Gambar 14. Potongan bangunan eksisting Stasiun Purwosari

Prinsip struktur grid yang dari dulu hingga sekarang menjadi teknik dasar dalam membangun tetap digunakan, hanya perubahan detail pengerjaan yang menjadikan konstruksi semakin berkembang dan kuat. Untuk pekerjaan struktur bawah menggunakan jenis tiang pancang, struktur badan menggunakan kolom berbentuk pola lingkaran, dan struktur atap menggunakan jenis bentang lebar yaitu space frame (lihat gambar 15).

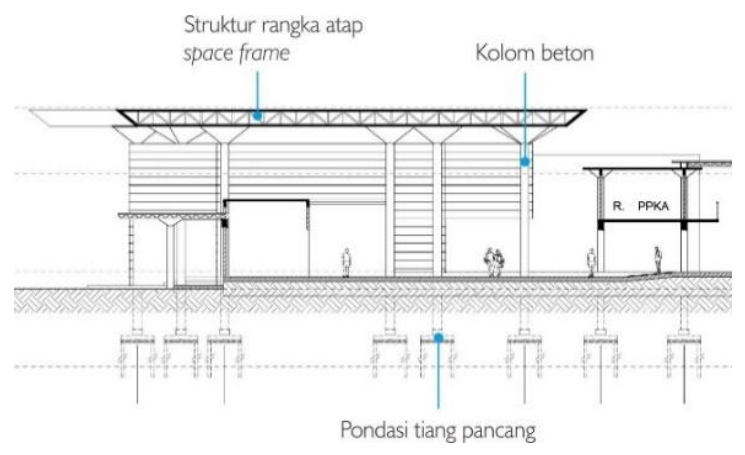

Gambar 15. Potongan bangunan Stasiun Purwosari baru

Sumber : Peneliti, 2018

Berdasarkan pembahasan yang dilakukan, penerapan desain harmony by contrast pada perancangan pengembangan Stasiun Purwosari, untuk konsep harmoni ditunjukkan pada aspek warna dan skala, sedangkan konsep kontras ditunjukkan pada aspek langgam/gaya arsitektur, konstruksi, dan material. 
Untuk memaksimalkan suasana harmony by contrast pada kawasan Stasiun Purwosari, penataan lanskap menjadi aspek penting dalam pengolahan desain. Penataan lanskap dibentuk dari garis pola imajiner yang berorientasi memusat ke emplasemen bangunan Stasiun Purwosari. Selain untuk membuka untuk public space juga memaksimalkan fungsi lanskap yang memperkuat dan mengekspose keberadaan 2 bangunan lama dan baru stasiun Purwosari. Gradasi warna menggunakan kombinasi batu candi, batu andesit, batu basal, dan beton ekspose (lihat gambar 12).

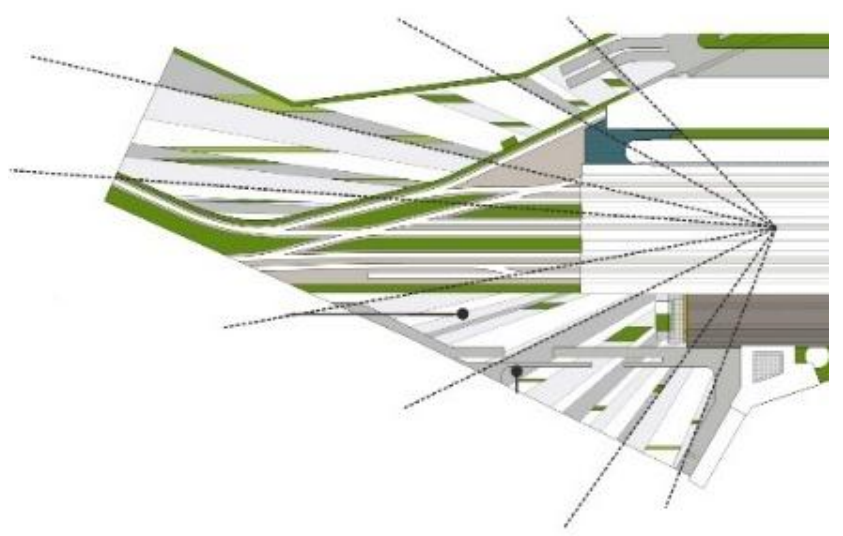

Gambar 12. Lanskap kawasan stasiun Purwosari

Elemen harmony by contrast disusun membentuk ruang baru pada pengembangan kawasan stasiun Purwosari (lihat gambar 13).

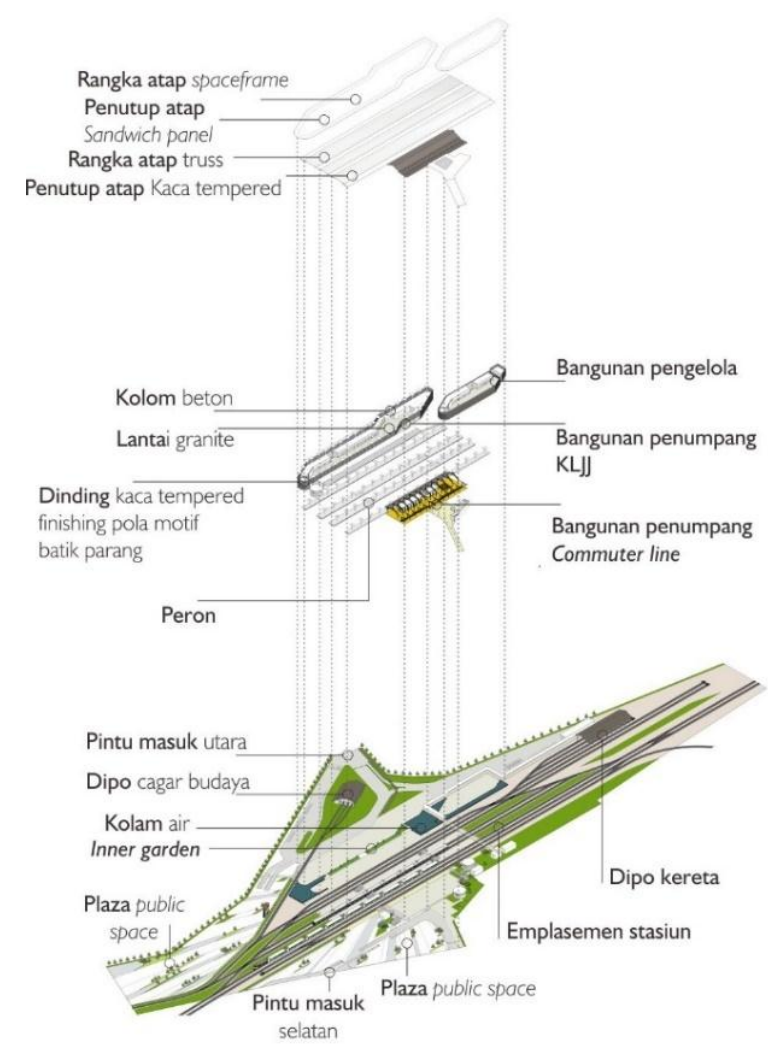

Gambar 13. Aksonometri kawasan stasiun Purwosari

Posisi fasad bangunan stasiun Purwosari memang terletak pada bangunan lama sisi selatan dan bangunan baru sisi utara (lihat gambar 14). Namun, ada titik dimana fasad bangunan terekspose secara keseluruhan. Yaitu dari perlintasan jalan Slamet Riyadi dengan rel kereta, tepatnya di barat daya kawasan stasiun Purwosari (lihat gambar 15, dan 16).

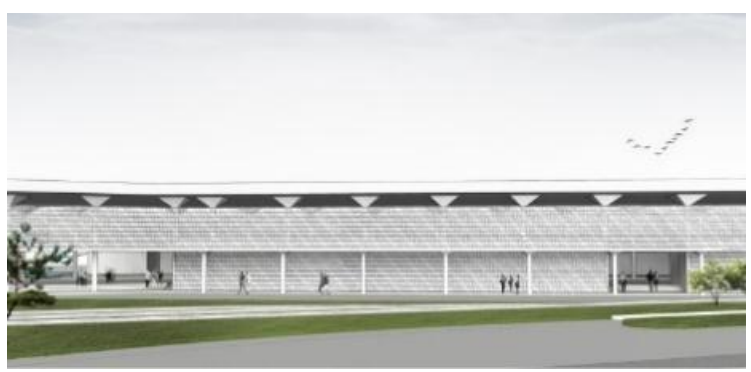

Gambar 14 . Fasad bangunan Purwosari baru.

Posisi ini menjadi vista utama yang didapatkan dari luar kawasan stasiun Purwosari, terlebih kedepannya perlintasan rel stasiun Purwosari 
akan dibangun fly over. Sehingga kedepannya vista harmony by contrast yang didukung penataan lanskap tapak terlihat lebih jelas dan terkespose keberadaannya dari jalan Slamet Riyadi (lihat gambar 17).

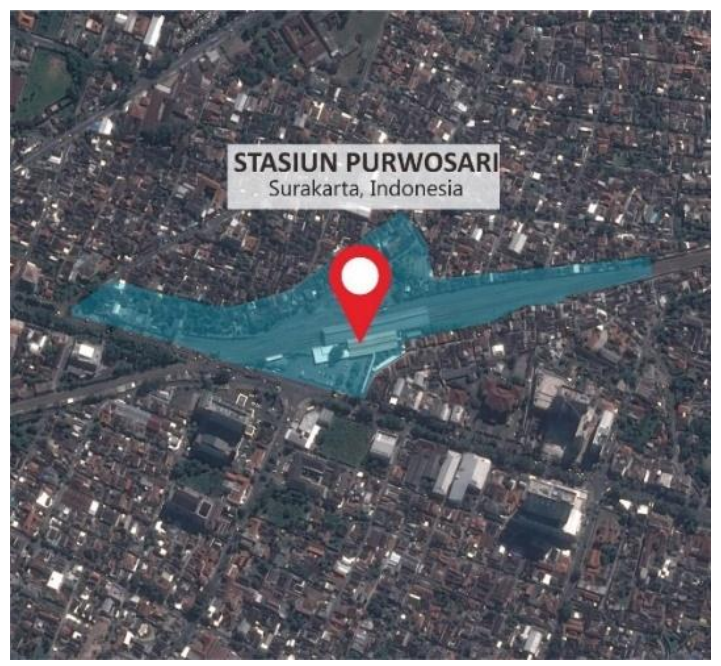

Gambar 15 . Lokasi kawasan pengembangan stasiun Purwosari

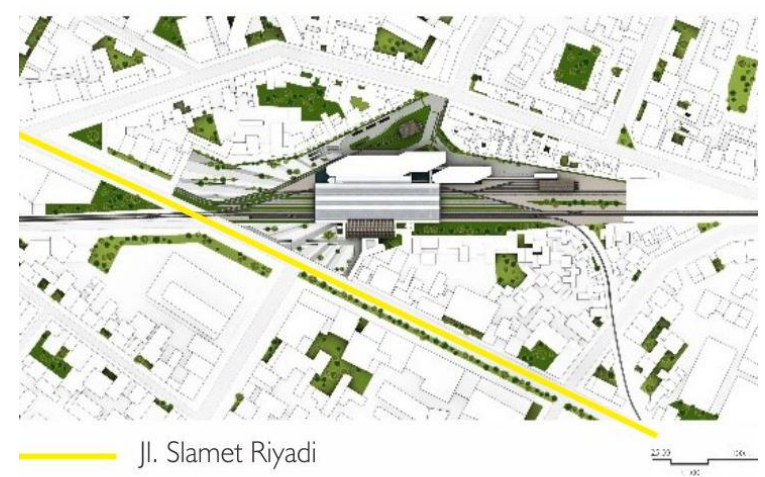

Gambar 16 . Blockplan kawasan pengembangan stasiun Purwosari

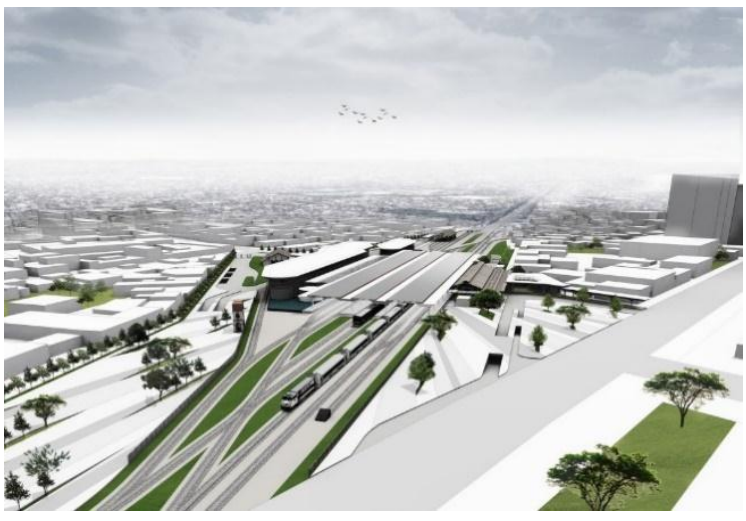

Gambar 17. Perspektif eksterior mata burung Kawasan stasiun Purwosari

\section{KESIMPULAN}

Berdasarkan pembahasan yang dilakukan sebelumnya, penerapan teori harmony by contrast diharapkan mampu menjawab pengembangan Stasiun Purwosari di Surakarta sehingga dapat menjadi bangunan baru dan cagar budaya sebagai bangunan yang harmoni nan kontras.

Penerapan teori harmony by contrast dalam konservasi bangunan cagar budaya akan memberikan ruang hidup untuk bangunan cagar budaya namun tidak semua desain bangunan baru sesuai dengan bangunan cagar budayanya, apabila tingkat intervensi yang diperlukan untuk memasukan bentuk desain baru pada gedung menimbulkan kerusakan / melunturkan pada nilai sejarahnya, maka fungsi tersebut dikatakan tidak sesuai dengan bangunannya. Desain bangunan baru pada kawasan bangunan cagar budaya harus mempertimbangkan apakah fungsi yang ingin dimasukan sesuai dengan bangunannya. Selain fungsi, lokasi menjadi salah satu pertimbangan dalam menambahkan fungsi baru dalam sebuah bangunan karena setiap lokasi memiliki kebutuhan yang berbedabeda.

Upaya kegiatan konservasi pengembangan kawasan stasiun Purwosari ini merupakan langkah dalam pemuliaan bangunan cagar budaya untuk tetap menjaga keutuhan dan keaslinan nilai sejarah yang terkandung didalamnya. 


\section{REFERENSI}

Brolin, Brent C. (1980). Architecture in Context: Fitting New Buildings with Olds. Van Nostrand Reinhold Company: Inggris.

Faatihah, Al. 2014. Revitalisasi Pasar Terapung Lok Bintan Di Banjarmasin Dengan Pendekatan Arsitektur Kontekstual. Surakarta : Universitas Sebelas Maret

Martin, Auditya. (2009). Transportasi Kereta Api Dalam Pembangunan Kota Solo Tahun 1900-1940. Surakarta : Universitas Sebelas Maret

Kementrian Pekerjaan Umum Republik Indonesia. (2007). Pedoman Teknis Pembangunan Bangunan Gedung Negara

Kementrian Perhubungan Republik Indonesia. (2015). Standar Pelayanan Minimum Angkutan Orang Dengan Kereta Api

Tim PT KAI. (2012). Pedoman Standarisasi Stasiun Kereta Api Indonesia Pt Kereta Api Indonesia (Persero). Bandung : PT Kereta Api Indonesia 